\title{
Expression and association of TRPC subtypes with Orai1 and STIM1 in human parathyroid
}

\author{
Ming Lu ${ }^{1,3}$, Robert Bränström ${ }^{1}$, Erik Berglund ${ }^{1}$, Anders Höög ${ }^{2}$, Peyman Björklund ${ }^{4}$, \\ Gunnar Westin ${ }^{4}$, Catharina Larsson ${ }^{1}$, Lars-Ove Farnebo ${ }^{1}$ and Lars Forsberg ${ }^{1}$ \\ Departments of ${ }^{1}$ Molecular Medicine and Surgery and ${ }^{2}$ Oncology-Pathology, Karolinska Institutet, Karolinska University Hospital L1:03, 171 76 Stockholm, Sweden \\ ${ }^{3}$ Department of Geriatric Endocrinology, First Affiliated Hospital of Guangxi Medical University, NanNing, People's Republic of China \\ ${ }^{4}$ Department of Surgical Sciences, Uppsala University Hospital, Uppsala University, Uppsala, Sweden \\ (Correspondence should be addressed to R Bränström; Email: robert.branstrom @ki.se)
}

\begin{abstract}
The mechanism behind $\mathrm{Ca}^{2+}$ entry into the parathyroid cells has been widely debated, and the molecular identities of the responsible ion channels have not been established yet. In this study, we show that the parathyroid cells lack voltage-operated $\mathrm{Ca}^{2+}$ channels. Passive store depletion by thapsigargin, on the other hand, induces a large non-voltageactivated non-selective cation current. The increase in intracellular $\mathrm{Ca}^{2+}$ caused by thapsigargin is attenuated by 2-aminoethoxydiphenyl borate, a blocker of store-operated $\mathrm{Ca}^{2+}$ entry (SOCE). Candidate molecules for non-voltageoperated $\mathrm{Ca}^{2+}$ signaling were investigated. These included members of the transient receptor potential canonical (TRPC) ion channel family, as well as $\mathrm{Ca}^{2+}$ release-activated $\mathrm{Ca}^{2+}$ modulator 1 (Orai1) and stromal interaction molecule 1 (STIM1) that are key proteins in the SOCE pathway. Using RT-PCR screening, quantitative real-time PCR, and western blot, we showed expression of TRPC1, TRPC4, and TRPC6; Orai1; and STIM1 genes and proteins in normal and adenomatous human parathyroid tissues. Furthermore, co-immunoprecipitation experiments demonstrated a ternary complex of TRPC1-Orai1-STIM1, supporting a physical interaction between these molecules in human parathyroid.
\end{abstract}

Journal of Molecular Endocrinology (2010) 44, 285-294

\section{Introduction}

Primary hyperparathyroidism (pHPT) is the second most common endocrine disease in the western populations (Nilsson et al. 2002) after diabetes. The underlying physiological disturbance is the inadequate inhibition of PTH secretion in response to elevated serum calcium. The stimulus-secretion coupling in the parathyroid cells is not completely understood. However, extracellular free calcium $\left(\mathrm{Ca}_{0}^{2+}\right)$ regulates PTH secretion from parathyroid cells by acting on a calcium-sensing receptor (CASR) expressed on the cell surface (Sherwood et al. 1970, Nemeth \& Scarpa 1987, Brown et al. 1993, Hofer \& Brown 2003). The CASR is a G-protein, phospholipase C (PLC)-linked, membrane-bound receptor, activation of which leads to increased levels of inositol trisphosphate $\left(\mathrm{IP}_{3}\right)$, and hence to $\mathrm{Ca}^{2+}$ release from intracellular stores (Hofer \& Brown 2003). It is generally considered that a high concentration of cytoplasmic free $\mathrm{Ca}^{2+}\left(\mathrm{Ca}_{\mathrm{i}}^{2+}\right)$ mediates an inhibition of parathyroid hormone secretion (Shoback et al. 1984). The parathyroid cells are unique in this respect, because in most other endocrine cells, elevated $\mathrm{Ca}_{\mathrm{i}}^{2+}$ stimulates hormone secretion. Since radioactively labeled $\mathrm{Ca}^{2+}$ enters the parathyroid cells and unspecific $\mathrm{Ca}^{2+}$ channel blockers prevent $\mathrm{Ca}^{2+}$ entry (Ridefelt et al. 1992), a transporting mechanism must exist in the plasma membrane. It has been suggested that $\mathrm{Ca}^{2+}$ entry into the parathyroid cells is mediated by L-type voltageoperated $\mathrm{Ca}^{2+}$ channels (VOCCs; Chang et al. 2001). However, the presence of these channels has not been proven (Muff et al. 1998). The aim of this work was to investigate what type of $\mathrm{Ca}^{2+}$ channels can be demonstrated in normal and adenomatous human parathyroid cells. We used electrophysiology and molecular biology techniques to explore the possibility that $\mathrm{Ca}^{2+}$ entry is mediated by VOCCs and/or non-selective cation channels, belonging to the family of transient receptor potential canonical-type (TRPC). In other cell systems, TRPCs have been implicated in store-operated $\mathrm{Ca}^{2+}$ entry (SOCE), and TRPC1 associated with $\mathrm{Ca}^{2+}$ release-activated $\mathrm{Ca}^{2+}$ modulator 1 (Orai1) and stromal interaction molecule 1 (STIM1) were the core components of store-operated $\mathrm{Ca}^{2+}$ channels (SOCs; Ambudkar \& Ong 2007, Ambudkar et al. 2007).

DOI: 10.1677/JME-09-0138 Online version via http://www.endocrinology-journals.org 


\section{Materials and methods}

\section{Cells for electrophysiology and $\mathrm{Ca}_{\mathrm{i}}^{2+}$ measurement}

Small pieces of human parathyroid tissues (both normal and adenoma) were transported immediately after surgery to the laboratory in sterile tubes, and prepared according to previously published protocol (Välimäki et al. 2003). Parathyroid tissue collection was carried out with approval from the local ethics committee. Pancreatic $\beta$-cells were isolated from adult obese mice $(o b / o b)$, and were prepared as described earlier (Bränström et al. 1998).

\section{Electrophysiology}

For electrophysiological experiments, cells were seeded into Petri dishes (Nunc, Roskilde, Denmark), and were incubated at $37^{\circ} \mathrm{C}$ and $5 \% \mathrm{CO}_{2}$ overnight in DMEM/ $\mathrm{F}-12+10 \%$ FCS medium. VOCC activity was recorded using the patch-clamp technique (Hamill et al. 1981) with a HEKA EPC-10 patch-clamp amplifier (HEKA Elektronik, Ludwigshafen, Germany). The standard extracellular solution (i.e. bath solution) contained the following $(\mathrm{mM})$ : $138 \mathrm{NaCl}, 5 \cdot 6 \mathrm{KCl}, 2 \cdot 6 \mathrm{CaCl}_{2}, 1 \cdot 2$ $\mathrm{MgCl}_{2}$, and 5 HEPES-NaOH at a $\mathrm{pH}$ of $7 \cdot 4$. For wholecell recordings of $\mathrm{Ca}^{2+}$ currents, the intracellular-like solution (i.e. pipette solution) consisted of the following (mM): $150 \mathrm{~N}$-methyl-D-glucamine (NMG), $110 \mathrm{HCl}, 1 \mathrm{MgCl}_{2}, 2 \mathrm{CaCl}_{2}, 10 \mathrm{EGTA}, 3 \mathrm{MgATP}$, and 5 HEPES-NaOH (pH 7-15). NMG was substituted for $\mathrm{K}^{+}$in the pipette solution to prevent outward-directed $\mathrm{K}^{+}$currents. Similarly, SOC currents were recorded using whole-cell configuration. Pipette solution was composed of the following $(\mathrm{mM}): 145 \mathrm{CsCl}, 10 \mathrm{EGTA}, 8$ $\mathrm{NaCl}, 10 \mathrm{MgCl}_{2}$, and 10 HEPES (pH $7 \cdot 2$ with $\mathrm{CsOH}$ ). Channel current traces were displayed according to the convention that upward deflection denotes outward currents. Pipettes were pulled from borosilicate using a P-2000 laser pipette puller (Sutter Instrument, Novato, CA, USA), and they had a resistance between 2 and $4 \mathrm{M} \Omega$. All the experiments were performed at a room temperature of $\sim 22^{\circ} \mathrm{C}$.

\section{Measurement of $\mathrm{Ca}_{\mathrm{i}}^{2+}$}

Cells were grown on glass cover slides in DMEM/ F-12+10\% FCS medium overnight until they attached to the slides, and were loaded with $3 \mu \mathrm{M}$ Fura-2 AM (Invitrogen) at $37^{\circ} \mathrm{C}$ for $30 \mathrm{~min}$. Experiments were performed using an extracellular solution containing the following $(\mathrm{mM}): 125 \mathrm{NaCl}, 4 \mathrm{KCl}, 20$ HEPES, $1 \mathrm{MgCl}_{2}, 0.8 \mathrm{NaH}_{2} \mathrm{PO}_{4}$, and 5.6 D-glucose. $\mathrm{CaCl}_{2}$ and substances were added as indicated. Slides with cells were kept in a perfusion chamber and exposed to an inverted fluorescence microscope (Axiovert $135 \mathrm{TV}$, Zeiss, Göttingen, Germany), and the cells were detected by a cooled charge-coupled device camera (CH250/KAF 1400, Photometrics, Tucson, AZ, USA) connected to an imaging system (Inovision, Durham, NC, USA). Fluorescence was provided by a SPEX fluorolog-2 CM1T11I spectrofluorometer (SPEX Industries, Edison, NJ, USA) with excitation wavelength at 340 and $380 \mathrm{~nm}$, and emission monitored at $505 \mathrm{~nm}$. Experiments were performed at $\sim 37^{\circ} \mathrm{C}$. Fluorescence intensity was analyzed using ISEE software for UNIX (Inovision). Thapsigargin, 2-aminoethoxydiphenyl borate (2-APB), and YM-58483 (also known as BTP-2) were all obtained from Sigma.

\section{Tissue samples of pHPT cases and controls}

In this study, 20 parathyroid adenomas that were collected from patients treated surgically for pHPT at Karolinska University Hospital, Sweden, and diagnosed histopathologically as chief cell parathyroid adenomas according to the World Health Organization classification were used (DeLellis et al. 2004). The adenomas, the details of which have been published previously ( $\mathrm{Lu}$ et al. 2008), were employed in RT-PCR, quantitative real-time ( $\mathrm{qRT}$ )-PCR, western blot, and co-immunoprecipitation (co-IP) experiments. Clinical data for the pHPT patients are age $61.5 \pm 14.7$ years, serum $\mathrm{Ca}^{2+} 2 \cdot 85 \pm 0 \cdot 20 \mathrm{mM}$ (reference $2 \cdot 20-2 \cdot 60 \mathrm{mM}$ ), PTH level $269 \pm 208 \mathrm{ng} / \mathrm{l}$ (reference $<65 \mathrm{ng} / \mathrm{l}$ ), and tumor weight $2 \cdot 8 \pm 2 \cdot 3 \mathrm{~g}$. For details, see Supplementary Table 2, see section on supplementary data given at the end of this article. Two biopsies from normal parathyroid glands were obtained from patients treated for nodular thyroid lesions when parathyroid glands had to be excised and reimplanted into the sternomastoid muscle for anatomical reasons. Both these patients had normal levels of PTH, serum $\mathrm{Ca}^{2+}$, and thyroid hormones preoperatively. They were both verified as histopathologically normal. In addition, anonymous normal uterine tissue was collected by an experienced pathologist, and was used as a positive control for western blot analyses. Standardized sampling procedures, tissue handling, and storage at $-70^{\circ} \mathrm{C}$ ensured representative tissue and good quality RNA and protein extracts of all the samples.

\section{Antibodies}

The following primary antibodies were used for western blot and immunoprecipitation experiments: rabbit polyclonal anti-TRPC1 and control antigen (Cat. No. ACC-010, Alomone Labs, Jerusalem, Israel); rabbit monoclonal anti-TRPC1 (EP1417Y; Cat. No. 
NB110-57630, Novus Biologicals, Littleton, CO, USA); rabbit polyclonal anti-TRPC4 and control antigen (Alomone Labs, Cat. No. ACC-018); rabbit polyclonal anti-TRPC6 and control antigen (Alomone Labs, Cat. No. ACC-017); mouse monoclonal anti-Orai1 (Abcam, Cat. No. ab54076); mouse monoclonal antiStim1 (BD Biosciences, Cat. No. G72120-050); and mouse monoclonal anti- $\beta$-actin (Cat. No. ab6276, Abcam, Cambridge, UK).

\section{Reverse transcription-PCR}

RT-PCR was used to screen for TRPC expression in normal and three pHPT samples. Total RNA was extracted using TRIzol reagent (Invitrogen) and was quantified using a spectrophotometer, and the purity and quality of the RNA were further confirmed by analysis in an Agilent 2100 Bioanalyzer (Agilent Technologies, Santa Clara, CA, USA). Total RNA $(3 \mu \mathrm{g})$ from each sample was reverse transcribed into $40 \mu \mathrm{l}$ cDNA applying the SuperScript III First-Strand Synthesis System for RT-PCR (Invitrogen, Cat. No. 18080-051). Two microliters of each cDNA were used for PCR amplification of TRPC1, TRPC3, TRPC4, TRPC5, TRPC6, and TRPC7 transcripts, which was carried out using optimized gene-specific primers (Table 1) and the Platinum Taq DNA polymerase high-fidelity kit (Invitrogen). The program was constituted of i) $94^{\circ} \mathrm{C}$ for $2 \mathrm{~min}$ and ii) $40-45$ cycles of $94^{\circ} \mathrm{C}$ for $30 \mathrm{~s}, 55^{\circ} \mathrm{C}$ for $30 \mathrm{~s}$, and $68^{\circ} \mathrm{C}$ for $1 \mathrm{~min}$. Human brain cDNA (Invitrogen, Cat. No. B1110033) was used as a positive control since all TRPC genes have been detected previously in human brain tissue (Riccio et al. 2002). The PCR products were subsequently size-verified by agarose gel electrophoresis, observed, and photographed under u.v. light. After purification using the PCR purification kit (Qiagen, Cat. No. Q28104), the products were confirmed by DNA sequencing with the assistance of KISeq, Karolinska Institutet.

\section{Quantitative real-time PCR}

Expression of TRPC1, TRPC4, and TRPC6; Orai1; and STIM1 was determined in 2 normal parathyroid and 20 adenoma samples (Supplementary Table 3, see section on supplementary data given at the end of this article). Five micrograms of total RNA from each sample were reverse transcribed into $40 \mu \mathrm{l} \mathrm{cDNA}$ using the methodology described above, which gave a final concentration of $125 \mathrm{ng} / \mu \mathrm{l}$. Gene expression was quantified using TaqMan Gene Expression Assays (Applied Biosystems) with gene-specific primers and TaqMan probes for TRPC1 (Hs00608195_m1), TRPC4 (Hs00175753_m1), and TRPC6 (Hs00211805_m1) Orail (Hs00385627_m1) and STIM1 (Hs00963373_m1) (for details see Supplementary Table 1, see section on supplementary data given at the end of this article), and an ABI realtime PCR 7900HF Fast System (Applied Biosystems). The real-time PCRs were performed in a final volume of $10 \mu \mathrm{l}$ with $4.5 \mu \mathrm{l}$ cDNA ( $\sim 20 \mathrm{ng}), 0.5 \mu \mathrm{l}$ TaqMan Gene Expression Assay $(20 \times)$, and $5 \mu \mathrm{l}$ TaqMan Universal PCR Master Mix. The amplification program included i) $95^{\circ} \mathrm{C}$ for $10 \mathrm{~min}$ and ii) 40 cycles of $95^{\circ} \mathrm{C}$ for $15 \mathrm{~s}$ and $60{ }^{\circ} \mathrm{C}$ for $1 \mathrm{~min}$. For each gene, a standard curve was created by serial dilution $(1: 10,1: 50,1: 250,1: 1250$, and 1:6250) of human brain cDNA (Invitrogen). To normalize the individual mRNA level, the housekeeping gene RPLPO (Hs99999902_m1) was amplified in parallel as an endogenous control. A no-template sample served as a negative control. Triplicate measurements were performed for all samples, and the experiments were performed on two separate occasions with consistent results.

\section{Western blot}

Total proteins were extracted and quantified with a dye-binding assay (Bradford 1976). The yield of the total protein samples was used for western blot and immunoprecipitation experiments. Protein samples

Table 1 Details of primers used for RT-PCR analyses of human TRPC genes

\begin{tabular}{|c|c|c|c|c|}
\hline & Accession no. & Orientation & Sequence $\left(5^{\prime}-3^{\prime}\right)$ & Amplicon length (bp) \\
\hline \multicolumn{5}{|l|}{ Gene } \\
\hline TRPC1 & NM_003304 & $\begin{array}{l}\text { Forward } \\
\text { Reverse }\end{array}$ & $\begin{array}{l}\text { ACAGCAAAGCAATGATACCT } \\
\text { AAGTCCGAAAGCCAAGTAAA }\end{array}$ & 620 \\
\hline TRPC3 & NM_003305 & $\begin{array}{l}\text { Forward } \\
\text { Reverse }\end{array}$ & $\begin{array}{l}\text { GTTGTGGAATGTGCTTGACT } \\
\text { TGAAAGGTGGAGGTAATGTT }\end{array}$ & 722 \\
\hline TRPC4 & NM_016179 & $\begin{array}{l}\text { Forward } \\
\text { Reverse }\end{array}$ & $\begin{array}{l}\text { CCTGGACATTTTGAAGTTTC } \\
\text { CTGCATGGTCAGCAATCAGT }\end{array}$ & 356 \\
\hline TRPC5 & NM_012471 & $\begin{array}{l}\text { Forward } \\
\text { Reverse }\end{array}$ & $\begin{array}{l}\text { GTGGCCTATGTCAAGTATAA } \\
\text { GGCAGTAGATAAAGAGGAAT }\end{array}$ & 214 \\
\hline TRPC6 & NM_004621 & $\begin{array}{l}\text { Forward } \\
\text { Reverse }\end{array}$ & $\begin{array}{l}\text { AGGATGACGCTGATGTGGAG } \\
\text { TCCTTCAGTTCCCCTTCGTT }\end{array}$ & 454 \\
\hline TRPC7 & NM_020389 & $\begin{array}{l}\text { Forward } \\
\text { Reverse }\end{array}$ & $\begin{array}{l}\text { TGGGATTATTAGTTGTGAATG } \\
\text { GATATCTTTCACAGTTCTCCC }\end{array}$ & 742 \\
\hline
\end{tabular}


were denatured by heating at $95^{\circ} \mathrm{C}$ for $5 \mathrm{~min}$, electrophoresed in $10 \%$ Tricine gels, and transferred onto nitrocellulose membranes. A Ponceau Red stain was used to assess the presence of protein after blotting. After blocking non-specific binding sites with $5 \%$ fatfree milk, the membranes were incubated overnight at $4{ }^{\circ} \mathrm{C}$ with appropriate primary antibodies for rabbit polyclonal anti-TRPC1 (dilution 1:200), anti-TRPC4 (1:200), anti-TRPC6 (1:200), anti-Orail (1:100), and anti-STIM1 (1:250), followed by incubation with secondary antibodies (goat anti-mouse IgG-HRP or goat anti-rabbit IgG-HRP) at a dilution of 1:20 000 for $1 \mathrm{~h}$ at room temperature. Immunoreactive bands were detected using enhanced chemiluminescence, and were exposed to a hyperfilm. Subsequent incubation with anti- $\beta$-actin was used as a control of protein loading and quality. To confirm signal specificity, primary antibodies were pre-incubated with peptide antigen (i.e. blocking peptide) for $1 \mathrm{~h}$ at room temperature and for $2 \mathrm{~h}$ at $4{ }^{\circ} \mathrm{C}$.

\section{Co-immunoprecipitation}

Co-IP was used to identify possible associations between TRPC1, Orai1, and/or STIM1 proteins. Precleared protein was obtained by incubating $1 \mathrm{mg}$ parathyroid adenoma protein (patient no. 18, see Supplementary Table 2) with $15 \mu \mathrm{l}$ protein G-Sepharose bead slurry for $1 \mathrm{~h}$ at $4{ }^{\circ} \mathrm{C}$ to reduce non-specific binding of proteins to the Sepharose beads. After centrifugation, $5 \mu$ of rabbit monoclonal anti-TRPC1 (EP1417Y), anti-Orai1, or antiSTIM1 antibody were added to the supernatant and incubated under rotation for $6 \mathrm{~h}$ at $4{ }^{\circ} \mathrm{C}$. Subsequently, $50 \mu \mathrm{l}$ of protein G-Sepharose beads were added, and rotation was continued for $4 \mathrm{~h}$. The beads were washed three times with ice-cold modified RIPA buffer, followed by resuspension of the Sepharose beads in $2 \times$ SDS sample buffer. The samples were heated at $95{ }^{\circ} \mathrm{C}$ for 5 min before electrophoresis and blotted, and signal visualization was done using TRPC1 (rabbit polyclonal), Orai1, or STIM1 primary antibody respectively. As a negative control, protein samples were mock-immunoprecipitated with an irrelevant antibody and treated in the same way as described above. In all the co-IP experiments, the respective antibodies recognized a band of the same and expected size in both the lysate and the immunoprecipitated samples, but not in the mock IP sample.

\section{Statistical analysis}

All data are given as mean \pm s.D. If not indicated, experiments were repeated at least three times. Statistical significance was analyzed using paired and unpaired $t$-tests or ANOVA for multiple groups, as appropriate. A $P$ value of $<0.05$ was considered significant.

\section{Results}

\section{Lack of functional VOCCs and demonstration of store-operated cation currents in parathyroid cells}

The possible existence of functional VOCCs in parathyroid cells was first addressed by voltage-clamping using the whole-cell configuration. Single parathyroid cells were voltage-clamped at $-70 \mathrm{mV}$, and were subsequently depolarized in steps of 10 to $+70 \mathrm{mV}$. As illustrated in Fig. 1A and B, this did not result in an

A Normal parathyroid

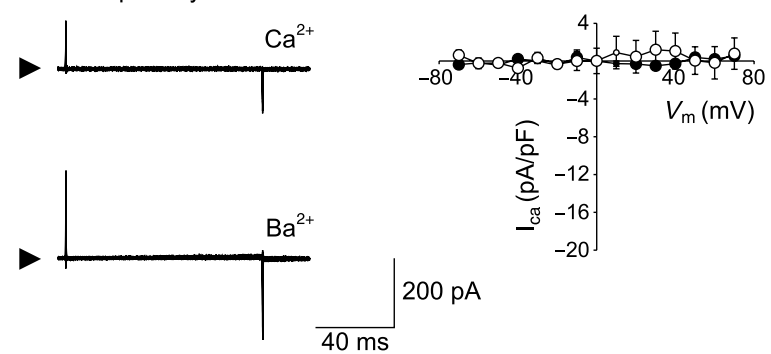

B Parathyroid adenoma
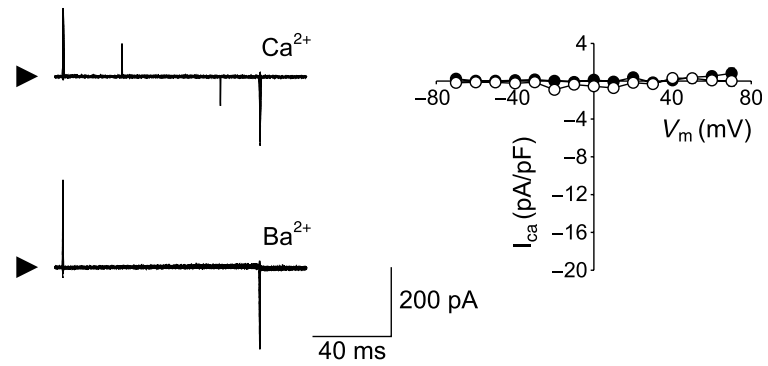

C

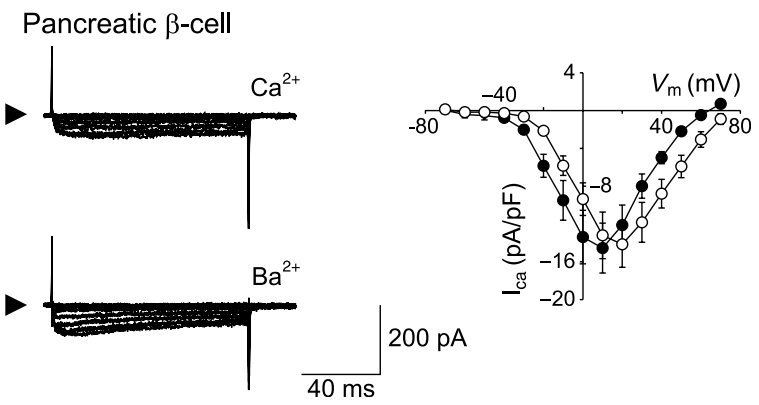

Figure 1 Patch-clamp experiments demonstrating the absence of VOCCs in parathyroid cells. Whole-cell $\mathrm{Ca}^{2+}$ current $\left(\mathrm{I}_{\mathrm{ca}}\right)$ was not recorded in normal $(A)$ or adenoma $(B)$ parathyroid cells after applying a depolarizing voltage protocol (between -70 and $+70 \mathrm{mV}$ in $10-\mathrm{mV}$ increments). Top trace and filled circles show results obtained with a total of $20 \mathrm{mM} \mathrm{Ca}^{2+}$ in the extracellular solution, and open circles represent results obtained with $20 \mathrm{mM}$ $\mathrm{Ba}^{2+}$. (C) Typical $\mathrm{Ca}^{2+}$ current in pancreatic $\beta$-cells after applying the same depolarizing voltage protocol. 
inward-directed current in normal parathyroid or adenoma cells. Application of the same protocol to pancreatic $\beta$-cells, used as a positive control, resulted in inward-directed currents, verifying that our solutions and patch-clamp protocol were suitable for recording of VOCCs (Fig. 1C). These experiments demonstrated that human parathyroid cells do not express a functional VOCC in the plasma membrane. In addition, human parathyroid cells (both normal and adenoma) were voltage-clamped at $0 \mathrm{mV}$, and every $2 \mathrm{~s}$, a voltage ramp from -80 to $+80 \mathrm{mV}$ was applied (rise time $400 \mathrm{~ms}$ ). In the pipette solution, $\mathrm{Cs}^{+}$ replaced NMG. As shown in Fig. 2A-C, addition of thapsigargin activated a non-selective cation current. The effect of thapsigargin on whole-cell current was rapid and slowly partly reversible (Fig. 2C).

\section{Measurement of $\mathrm{Ca}_{\mathrm{i}}^{2+}$}

Activation of SOCE was assessed by depletion of intracellular $\mathrm{Ca}^{2+}$ store with thapsigargin. In Fig. 3A, $\mathrm{Ca}^{2+}$ was withdrawn from extracellular solution, and

A
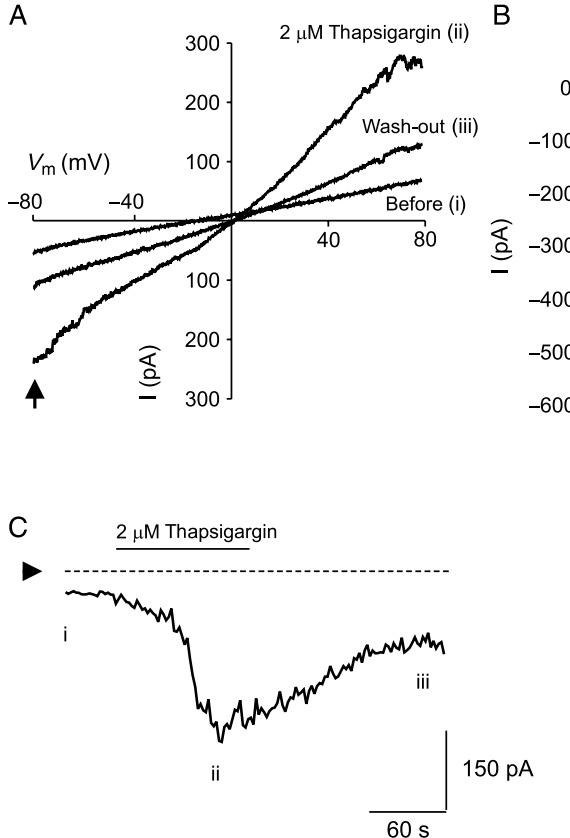

Figure 2 Patch-clamp measurement of SOC currents in human parathyroid cells. SOC currents were estimated using whole-cell configuration and voltage ramp from -80 to $+80 \mathrm{mV}$ every $2 \mathrm{~s}$. Bath solution contained standard extracellular solution (see Materials and methods) supplemented with $17.4 \mathrm{mM} \mathrm{CaCl}_{2}$ (final concentration $20 \mathrm{mM} \mathrm{CaCl}_{2}$ ). (A) Ramp current before, during, and after the addition of $2 \mu \mathrm{M}$ thapsigargin. (B) Summary of ramp current at $-80 \mathrm{mV}$ (indicated by arrow in $\mathrm{A}$ ) in the absence and presence of thapsigargin $(n=3)$. Plotting of ramp current at $-80 \mathrm{mV}$ showed a rapid and partly reversible effect on whole-cell current after the addition of thapsigargin (C). ${ }^{* \star} P<0.01$. the cells were subsequently exposed to $1.5 \mathrm{mM} \mathrm{Ca}_{0}^{2+}$, prior to and after the addition of thapsigargin. Addition of thapsigargin, in the absence of $\mathrm{Ca}_{0}^{2+}$, caused a small increase in $\mathrm{Ca}_{\mathrm{i}}^{2+}$ in $\sim 50 \%$ of the cells studied. In all the experiments, a larger rise in $\mathrm{Ca}_{\mathrm{i}}^{2+}$ was seen with $1.5 \mathrm{mM}$ $\mathrm{Ca}^{2+}$ after exposure to thapsigargin. In Fig. 3B, 2-APB caused a transient increase in $\mathrm{Ca}_{i}^{2+}$, followed by a lowering of $\mathrm{Ca}_{i}^{2+}$. The lower level was kept even when $1.5 \mathrm{mM} \mathrm{Ca}_{0}^{2+}$ was added. A sharp elevation of $\mathrm{Ca}_{\mathrm{i}}^{2+}$ was seen after the removal of 2-APB, suggesting that the effect of 2-APB on $\mathrm{Ca}^{2+}$ entry is reversible. YM-58483, also known as BTP-2, which has been shown to inhibit TRCP3 and 5, but not TRCP1, did not affect the elevation of $\mathrm{Ca}_{i}^{2+}$ caused by thapsigargin (Fig. 3C).

\section{Gene expression of TRPC1, TRPC4, and TRPC6; Orai1; and STIM1 in human parathyroid}

RT-PCR products of expected lengths corresponding to TRPC1, TRPC4, and TRPC6 were detected in the normal parathyroid and adenoma samples used for screening of TRPC expression (Fig. 4A). No products were obtained for TRPC3, TRPC5, or TRPC7 in any of these samples. In support of the specificity and sensitivity of the assay, all TRPCs were readily amplified from human brain cDNA that was used as a positive control, while no product was detected in the RT-negative control. Furthermore, all PCR products were verified by sequencing, which revealed 100\% identity to published human sequences.

Gene expression in parathyroid tissues was further analyzed for TRPC1, TRPC4, and TRPC6 in an extended series of 20 parathyroid adenoma and 2 normal parathyroid samples by TaqMan quantitative real-time PCR (Fig. 4B). Expression of Orail and STIM1 was similarly studied. All genes were found expressed in the normal parathyroid and adenomas studied (complete qRT-PCR results may be found in Supplementary Table 3). No statistical comparison was made between normal and adenoma samples since only two normal parathyroids were available for analysis, whereas the expression of TRPC1 was significantly larger than that of TRPC4 and TRPC6. These findings confirm the results obtained from RT-PCR screening, and further demonstrate that TRPC1, TRPC4, and TRPC6; Orai1; and STIM1 are the generally expressed genes in parathyroids.

\section{Protein expression of TRPC1, TRPC4, and TRPC6; Orai1; and STIM1 in parathyroid tissue}

Protein expression of TRPC1, TRPC4, and TRPC6; Orai1; and STIM1 was subsequently determined in parathyroid adenomas. Positive expression of the expected molecular weights was detected in all the 20 

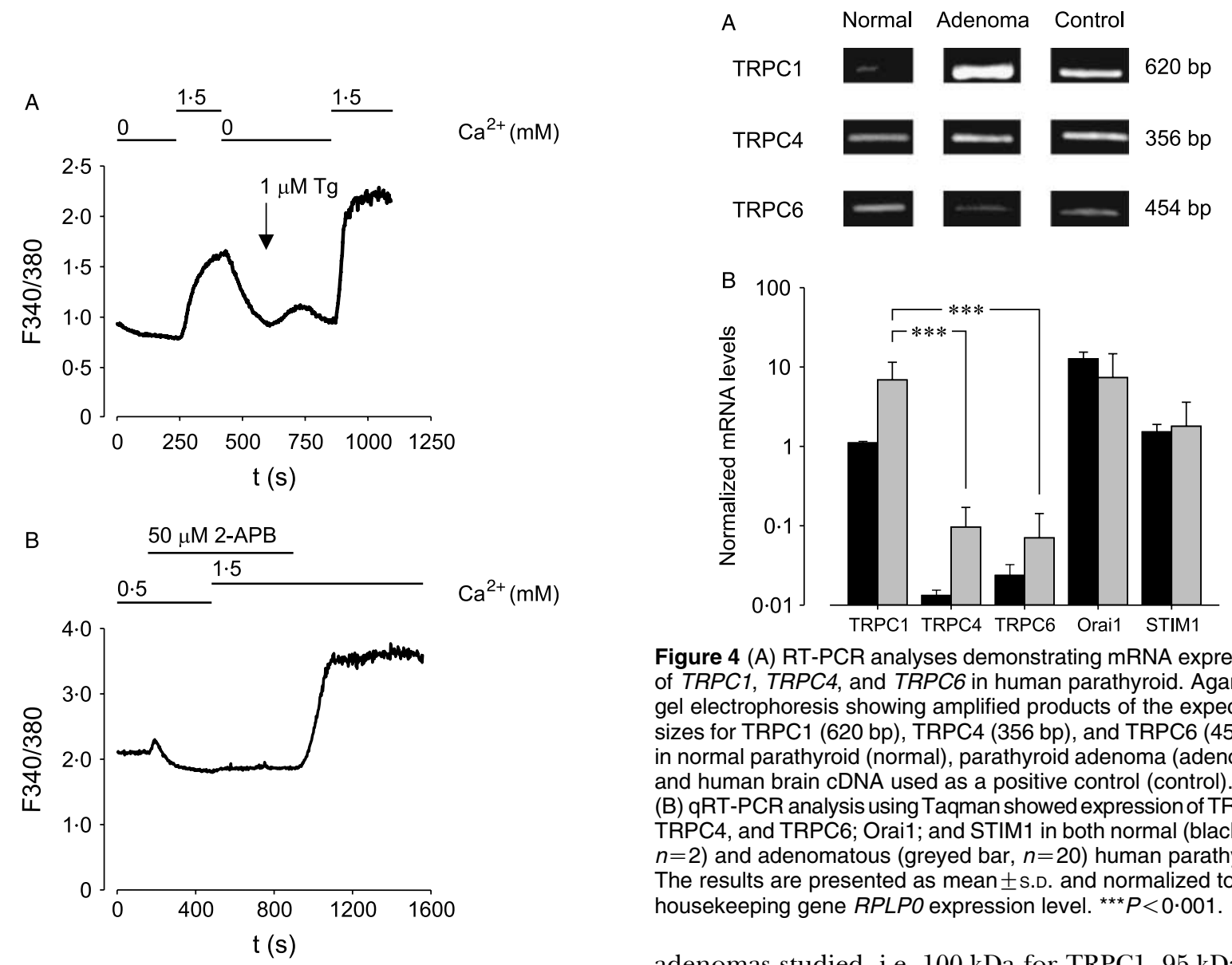

C

$50 \mu \mathrm{M} 2-\mathrm{APB}$
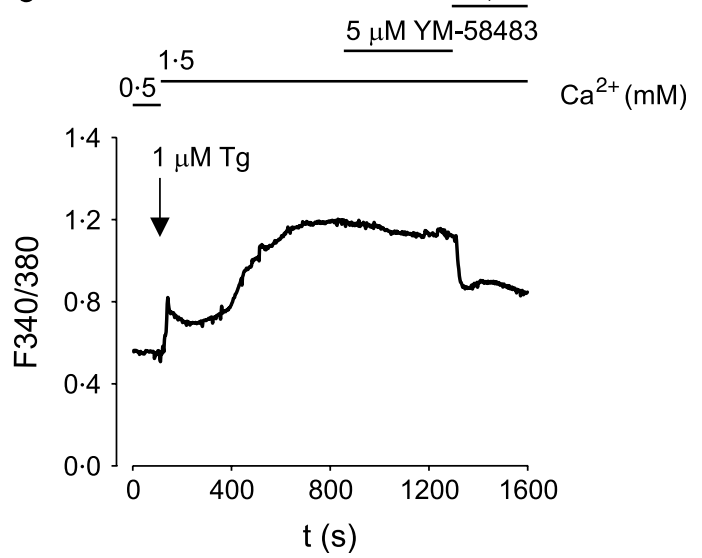

Figure 3 Recordings of $\mathrm{Ca}_{\mathrm{i}}^{2+}$ using Fura-2. A step increase in $\mathrm{Ca}_{\mathrm{o}}^{2+}$ from 0 to $1.5 \mathrm{mM}$ caused an increase in $\mathrm{Ca}_{\mathrm{i}}^{2+}$. The response was much enhanced in the presence of thapsigargin (A).

The effect of an increased $\mathrm{Ca}_{\circ}^{2+}$ was inhibited by 2-APB (B).

The elevated level of $\mathrm{Ca}_{i}^{2+}$ after step increase in $\mathrm{Ca}_{o}^{2+}$ to $1.5 \mathrm{mM}$ and the addition of thapsigargin was blocked by $50 \mu \mathrm{M}$ 2-APB but not by $5 \mu \mathrm{M}$ YM-58483 (C). At least five cells were tracked and recorded in each experiment in parallel, and at least three experiments were conducted for each protocol with a similar result.

Figure 4 (A) RT-PCR analyses demonstrating mRNA expression of TRPC1, TRPC4, and TRPC6 in human parathyroid. Agarose gel electrophoresis showing amplified products of the expected sizes for TRPC1 (620 bp), TRPC4 (356 bp), and TRPC6 (454 bp) in normal parathyroid (normal), parathyroid adenoma (adenoma), and human brain cDNA used as a positive control (control). (B) qRT-PCR analysis using Taqman showed expression of TRPC1, TRPC4, and TRPC6; Orai1; and STIM1 in both normal (black bar, $n=2$ ) and adenomatous (greyed bar, $n=20$ ) human parathyroid. The results are presented as mean \pm s.D. and normalized to housekeeping gene RPLPO expression level. ${ }^{* \star} P<0 \cdot 001$.

adenomas studied, i.e. $100 \mathrm{kDa}$ for TRPC1, $95 \mathrm{kDa}$ for TRPC4, $110 \mathrm{kDa}$ for TRPC6, $30 \mathrm{kDa}$ for Orail, and $85 \mathrm{kDa}$ for STIM1 (Fig. 5A-C and Supplementary Figure 1, see section on supplementary data given at the end of this article). The level of expression varied between the individual samples for all proteins. In the control experiments, the primary antibodies were preincubated with blocking peptides before incubation with the western blot membranes. In all cases, this resulted in loss of the expected protein product, thus confirming the specificity of the findings. Furthermore, total protein extracts from human uterus, rat brains, or rat pancreas served as a positive control, which revealed a strong signal at the expected molecular weight in all cases.

\section{Demonstration of TRPC1-Orai1-STIM1 ternary complex in human parathyroid}

Possible interactions between TRPC1, STIM1, and/or Orail were further examined by co-IP experiments. To verify a true association between the proteins, TRPC1, Orail, or STIM1 antibodies were used as bait in the co-IP, and the same antibodies were then used to detect the proteins in each IP fraction. The IP fraction 

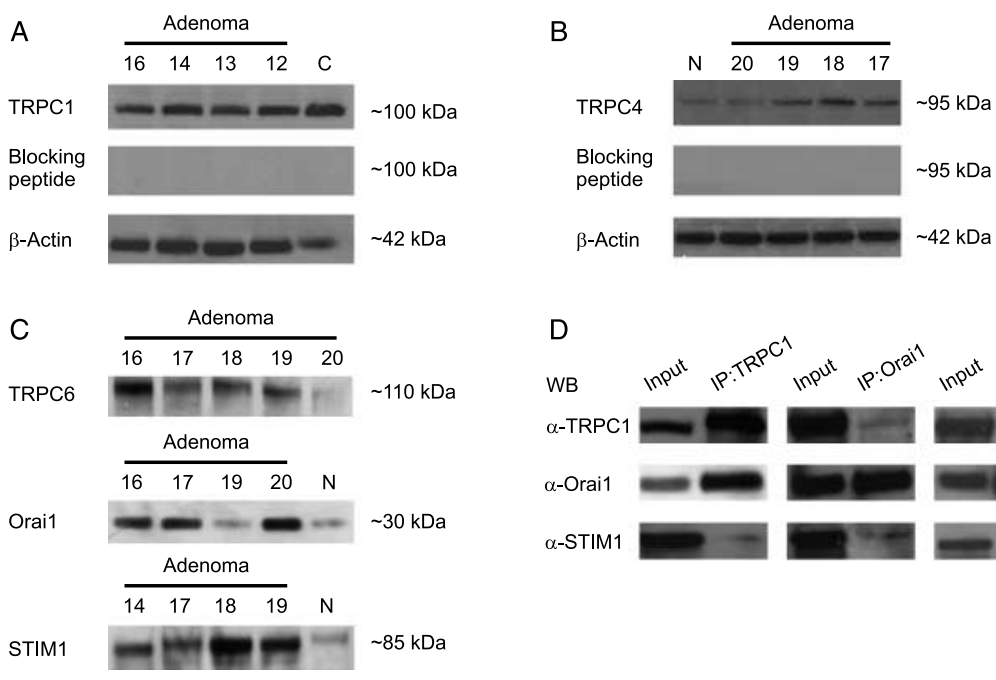

Figure 5 Western blot analysis of TRPC1 (A) and TRPC4 (B) expression in a panel of parathyroid adenoma tissues and human uterus used as a positive control (C). A protein product of the expected size ( $\sim 100 \mathrm{kDa}$, TRPC1, and $\sim 95 \mathrm{kDa}$, TRPC4) was revealed, and the specificity was verified by peptide neutralization (peptide) of the antibody prior to membrane incubation. $\beta$-Actin served as a loading control, and ' $N$ ' denotes normal parathyroid tissue. (C) A representative western blot of TRPC6 ( $\sim 110 \mathrm{kDa})$, Orai1 $(\sim 30 \mathrm{kDa})$, and STIM1 $(\sim 85 \mathrm{kDa})$ showing expression in parathyroid adenoma tissue. Numbers above western blot lane represent patient numbers. (D) Co-immunoprecipitation analysis showing interaction between TRPC1, Orai1, and STIM1. Each row under WB represents the result revealed from western blot using an appropriate antibody. Input indicates cell lysates without pull-down performance, e.g. 'IP:TRPC1' represents the immunoprecipitate using TRPC1 antibody to pull down interacting proteins using the same 'input' cell lysate as the starting material. Western blot analysis of TRPC1, TRPC4, TRPC6, Orai1, and STIM1 was performed using rabbit polyclonal anti-TRPC1 antibody (1:200), rabbit polyclonal anti-TRPC4 antibody (1:150), rabbit polyclonal anti-TRPC6 antibody (1:200), mouse monoclonal anti-Orai1 antibody (1:250), and mouse monoclonal anti-STIM1 antibody (1:100) respectively.

revealed a distinct signal at the expected weight from all the three proteins evaluated (Fig. 5D), but not from the mock IP (data not shown). The strongest signals in the IP fraction were revealed using Orail antibody as bait. Using STIM1 antibody revealed a clear but rather weaker signal compared with the other antibody that was used. The interaction was demonstrated and verified using any of the corresponding antibodies as bait. The co-IP was repeated twice with identical results. The concordant results from the co-IP experiment show that a TRPC1-Orai1-STIM1 ternary complex does exist in human parathyroid tissues.

\section{Discussion}

Intracellular $\mathrm{Ca}^{2+}$ is likely to have a pivotal role in the stimulus-secretion coupling in the parathyroid cells, since alterations in $\mathrm{Ca}_{\mathrm{i}}^{2+}$ have a major impact on hormone secretion (Shoback et al. 1984, Mihai et al. 2000). Alterations of extracellular $\mathrm{Ca}^{2+}$ levels and addition of $\mathrm{Ca}^{2+}$ channel blockers have indicated that $\mathrm{Ca}^{2+}$ influx is probably an important source for changes in $\mathrm{Ca}_{i}^{2+}$. However, many studies have attempted to characterize the mechanism(s) controlling $\mathrm{Ca}_{\mathrm{i}}^{2+}$ (Wallace et al. 1983, Muff et al. 1998), but the nature of the mechanism transporting $\mathrm{Ca}^{2+}$ into the parathyroid cells is still uncertain. One issue debated during the past two decades has been whether or not the parathyroid cells express a functional VOCC in the plasma membrane (Hove \& Sand 1981, Wallace et al. 1983). High potassium, which decreases $\mathrm{Ca}_{i}^{2+}$ (Shoback \& Brown 1984), stimulated PTH secretion, a finding which does not support the presence of VOCC, even though L-type calcium channel in parathyroid cells has been suggested (Chang et al. 2001, Yokoyama et al. 2009). In this study, we could not demonstrate any VOCC in parathyroid cells using a protocol that unequivocally demonstrates the presence of VOCC in the pancreatic $\beta$-cells. Therefore, non-selective cation channels that mediate SOCE have to be considered, even though the presence or absence of VOCC does not rule out the coexistence of non-selective cation channels.

SOCE is stimulated by depletion of $\mathrm{Ca}^{2+}$ from intracellular calcium stores, and is mediated by activation of specific plasma membrane channels, 
termed SOCs. This activation produces a biphasic increase in $\mathrm{Ca}_{i}^{2+}$, starting with a rapid $\mathrm{Ca}^{2+}$ release from ER stores, followed by a slower $\mathrm{Ca}^{2+}$ entry from outside the cell. This pattern, typical of PLC-coupled receptors (e.g. CASR), has also been demonstrated in parathyroid cells (Mihai \& Farndon 2000). Thapsigargin, a specific inhibitor of $\mathrm{Ca}^{2+}$-ATPase on intracellular stores, has been widely used as a tool to activate SOCE. Our electrophysiological studies showed a current which increased sixfold in the presence of thapsigargin, indicating the activation of SOCs. Even though thapsigargin irreversibly blocks $\mathrm{Ca}^{2+}$-ATPase activity, whole-cell current decays with time, most likely reflecting channel 'run-down'. The electrophysiological findings, in combination with recordings of $\mathrm{Ca}_{\mathrm{i}}^{2+}$ showing a large rise in $\mathrm{Ca}_{\mathrm{i}}^{2+}$ by $1.5 \mathrm{mM} \mathrm{Ca}^{2+}$ after thapsigargin treatment, are a strong indication for the presence of SOCs in human parathyroid cells.

Interestingly, the characteristics of SOCs in different cell types are quite distinct, suggesting diversity in the channel components (Liu et al. 2004, Beech 2005, Parekh \& Putney 2005). The canonical-type family of TRP channels is different from other groups of ion channels in displaying a huge diversity in ion selectivities, modes of activation, and the permeability to cations. All six members of the TRPC-type TRP channel (TRPC1, 3-7) have been proposed to be involved in both the receptor-operated and SOCE, which is linked to the PLC activation and inositol phospholipid breakdown signaling cascade (Pedersen et al. 2005). Emptying intracellular $\mathrm{Ca}^{2+}$ store with thapsigargin has been shown to activate $\mathrm{Ca}^{2+}$ influx through the plasma membrane presumably via TRPC (Ambudkar et al. 2007). Among the TRPC homologs most consistently associated with SOCs is TRPC1, which is required for SOCE in many cell types, e.g. salivary gland, keratinocytes, and smooth muscle cells (Liu et al. 2004, Cai et al. 2006, Dietrich et al. 2006). Overexpression of TRPC1 has been shown to have a pathological impact in other tissues, e.g. arterial smooth muscle (Bergdahl et al. 2005).

The CASR is expressed in plasma membrane, and is postulated to be the key player of $\mathrm{Ca}^{2+}$ signaling in the parathyroid cells (Brown et al. 1993). CASR is a G-protein, PLC-linked receptor, and has previously been shown to activate non-selective cation channels (e.g. TRPC) in breast cancer cells (Pedersen et al. 2005). A recent study has demonstrated the need for TRPC1 in the CASR-mediated $\mathrm{Ca}^{2+}$ oscillation in human embryonic kidney cells (Rey et al. 2006). Here, we demonstrated endogenous expression of TRPC1, TRPC4, and TRPC6 genes and proteins in normal parathyroid and pHPT. Concordant results were obtained by RT-PCR, qRT-PCR, and sequencing of PCR products. Expression of the corresponding protein was verified by western blot analyses. Blocking experiments with corresponding immunizing peptides confirmed the specificity of our western blot findings. Since qRT-PCR results show that TRPC1 has a higher expression level compared with TRPC4 and TRPC6 in parathyroid cells, we assume that TRPC1 is likely to be a key protein for SOCs in human parathyroid cells. Since no specific TRPC1 channel blockers are available, 2-APB and YM-58483, two commonly used SOC blockers, were used. Recordings of $\mathrm{Ca}_{\mathrm{i}}^{2+}$ show that 2-APB totally blocks $\mathrm{Ca}^{2+}$ entry in parathyroid cells, whereas YM- 58483 has only a mild, if any, effect. 2-APB has been shown as a reliable SOC blocker (Bootman et al. 2002). It has no effect on VOCC, and has the capability to block different TRPC isoforms, including TRPC1, TRPC3, TRPC6, and TRPC7. YM-58493, on the other hand, is a new potential SOC blocker (He et al. 2005), shown to have blocking effect on TRPC3 and TRPC5 (Ishikawa et al. 2003). The lack of effect of YM-58483 on $\mathrm{Ca}_{\mathrm{i}}^{2+}$ is most likely due to the absence of TRPC3 and TRPC5 in human parathyroid cells. The potent effect of 2-APB on $\mathrm{Ca}^{2+}$ entry further supports the existence of SOCs in human parathyroid.

A recent study has demonstrated that STIM1 and Orail are required for TRPC1-dependent SOC function, and that STIM1, located in junctional ER, is associated with Orail and TRPC1 in specific plasma membrane microdomains during activation of SOCE (Ong et al. 2007). In our study, we demonstrated an endogenous expression of the Orail and STIM1 genes and corresponding proteins in parathyroid tissues. To further clarify a putative interaction and thereby elucidate possible cellular signaling pathways, we performed co-IP using antibodies raised against TRPC1, STIM1, or Orail. In all the three different co-IP setups, the TRPC1, STIM1, and Orail proteins were pulled down together. IP products were detected in all co-IP fractions at the expected size although at varying intensities. The strongest signal was revealed using the Orail antibody as the co-IP bait. A clear but weaker signal became visible using STIM1 antibody, probably due to low antibody-binding capacity. To evaluate the quantitative contribution of individual SOCs in the parathyroid, a comprehensive investigation is needed, in which the siRNA approach would seem to be best suited. The novel data presented here will provide a useful guide in this regard.

In summary, our study provides evidence for a close association between TRPC1, Orai1, and STIM1, which was demonstrated for the first time in human parathyroid.

\section{Supplementary data}

This is linked to the online version of the paper at http://dx.doi.org/ 10.1677/JME-09-0138. 


\section{Declaration of interest}

The authors declare that there is no conflict of interest that could be perceived as prejudicing the impartiality of the research reported.

\section{Funding}

This work was supported by grants from the Swedish Research Council, the Novo Nordisk Foundation, Funds of the Karolinska Institute, the Tore Nilsson Foundation, the Turing Foundation, the Jeansson Foundations, the Åke Wiberg Foundation, the Göran Gustavsson Foundation for Research in Natural Sciences and Medicine, Magn. Bergvall Foundations, the Stockholm County Council, the Swedish Cancer Foundation, and the Knut and Alice Wallenberg Foundation.

\section{References}

Ambudkar IS \& Ong HL 2007 Organization and function of TRPC channelosomes. Pflügers Archiv: European Journal of Physiology $\mathbf{4 5 5}$ 187-200.

Ambudkar IS, Ong HL, Liu X, Bandyopadhyay BC \& Cheng KT 2007 TRPC1: the link between functionally distinct store-operated calcium channels. Cell Calcium 42 213-223.

Beech DJ 2005 TRPC1: store-operated channel and more. Pflügers Archiv: European Journal of Physiology 451 53-60.

Bergdahl A, Gomez MF, Wihlborg AK, Erlinge D, Eyjolfson A, Xu SZ, Beech DJ, Dreja K \& Hellstrand P 2005 Plasticity of TRPC expression in arterial smooth muscle: correlation with store-operated $\mathrm{Ca}^{2+}$ entry. American Journal of Physiology. Cell Physiology 288 C872-C880.

Bootman MD, Collins TJ, Mackenzie L, Roderick HL, Berridge MJ \& Peppiatt CM 2002 2-Aminoethoxydiphenyl borate (2-APB) is a reliable blocker of store-operated $\mathrm{Ca}^{2+}$ entry but an inconsistent inhibitor of InsP3-induced $\mathrm{Ca}^{2+}$ release. FASEB Journal 16 1145-1150.

Bradford MM 1976 Rapid and sensitive method for the quantitation of microgram quantities of protein utilizing the principle of protein-dye binding. Analytical Biochemistry 72 248-254.

Bränström R, Corkey BE, Berggren PO \& Larsson O 1998 Evidence for a unique long chain acyl-CoA ester binding site on the ATP-regulated potassium channel in mouse pancreatic beta cells. Journal of Biological Chemistry 272 17390-17394.

Brown EM, Gamba G, Riccardi D, Lombardi M, Butters R, Kifor O, Sun A, Hediger MA, Lytton J \& Hebert SC 1993 Cloning and characterization of an extracellular $\mathrm{Ca}^{2+}$-sensing receptor from bovine parathyroid. Nature 366 575-580.

Cai S, Fatherazi S, Presland RB, Belton CM, Roberts FA, Goodwin PC, Schubert MM \& Izutsu KT 2006 Evidence that TRPC1 contributes to calcium-induced differentiation of human keratinocytes. Pflügers Archiv: European Journal of Physiology 452 43-52.

Chang W, Pratt SA, Chen TH, Tu CL, Mikala G, Schwatz A \& Shoback D 2001 Parathyroid cells express dihydropyridinesensitive cation currents and L-type calcium channel subunits. American Journal of Physiology. Endocrinology and Metabolism 281 E180-E189.

DeLellis RA, Lloyd RV, Heitz PU \& Eng C 2004. Pathology and Genetics of the Tumours of Endocrine Organs, WHO Classification of Tumours, Lyon: IARC Press.

Dietrich A, Chubanov V, Kalwa H, Rost BR \& Gudermann T 2006 Cation channels of the transient receptor potential superfamily: their role in physiological and pathophysiological processes of smooth muscle cells. Pharmacology and Therapeutics 112 $744-760$.
Hamill OP, Marty A, Neher E, Sakmann B \& Sigworth FJ 1981 Improved patch-clamp techniques for high-resolution current recording from cells and cell-free membrane patches. Pflügers Archiv: European Journal of Physiology 391 85-100.

He LP, Hewavitharana T, Soboloff J, Spassova MA \& Gill DL 2005 A functional link between store-operated and TRPC channels revealed by the 3,5-bis(trifluoromethyl) pyrazole derivative, BTP2. Journal of Biological Chemistry 280 10997-11006.

Hofer AM \& Brown EM 2003 Extracellular calcium sensing and signaling. Nature Reviews. Molecular Cell Biology 4 530-538.

Hove K \& Sand O 1981 Evidence for a function of calcium influx in the stimulation of hormone release from the parathyroid gland in the goat. Acta Physiologica Scandinavica 113 37-43.

Ishikawa J, Ohga K, Yoshin T, Takezawa R, Ichikawa A, Kubota H \& Yamada T 2003 A pyrazole derivative, YM-58483, potently inhibits store-operated sustained $\mathrm{Ca}^{2+}$ influx and IL-2 production in T lymphocytes. Journal of Immunology 170 4441-4449.

Liu X, Groschner K \& Ambudkar IS 2004 Is distinct $\mathrm{Ca}(2+)$ permeable cation currents are activated by internal $\mathrm{Ca}(2+)$-store depletion in RBL-2H3 cells and human salivary gland cells, HSG and HSY. Journal of Membrane Biology 200 93-104.

Lu M, Forsberg L, Höög A, Juhlin CC, Vukojević V, Larsson C, Conigrave AD, Delbridge LW, Gill A, Bark C et al. 2008 Heterogeneous expression of SNARE proteins SNAP-23, SNAP-25, Syntaxin 1 and VAMP in human parathyroid tissue. Molecular and Cellular Endocrinology 287 72-80.

Mihai R \& Farndon JR 2000 Parathyroid disease and calcium metabolism. British Journal of Anaesthesia 85 29-43.

Mihai R, Lai T, Schofield GJ \& Farndon JR 2000 Changes in cytoplasmic calcium determine the secretory response to extracellular cations in human parathyroid cells: a confocal microscopy study using FM1-43 dye. Biochemical Journal 352 353-361.

Muff R, Nemeth EF, Haller-Brem S \& Fischer JA 1998 Regulation of hormone secretion and cytosolic $\mathrm{Ca}^{2+}$ by extracellular $\mathrm{Ca}^{2+}$ in parathyroid cells and C-cells: role of voltage-sensitive $\mathrm{Ca}^{2+}$ channels. Archives of Biochemistry and Biophysics $\mathbf{2 6 5}$ 128-135.

Nemeth EF \& Scarpa A 1987 Rapid mobilization of cellular $\mathrm{Ca}^{2+}$ in bovine parathyroid cells evoked by extracellular divalent cations: evidence for a cell surface calcium receptor. Journal of Biological Chemistry 262 5188-5196.

Nilsson IL, Yin L, Lundgren E, Rastad J \& Ekbom A 2002 Clinical presentation of primary hyperparathyroidism in Europe nationwide cohort analysis on mortality from nonmalignant causes. Journal of Bone and Mineral Research 17 N68-N74.

Ong HL, Cheng KT, Liu X, Bandyopadhyay BC, Paria BC, Soboloff J, Pani B, Gwack Y, Srikanth S, Singh BB et al. 2007 Dynamic assembly of TRPC1-STIM1-Orail ternary complex is involved in store-operated calcium influx: evidence for similarities in store-operated and calcium release-activated calcium channel components. Journal of Biological Chemistry $\mathbf{2 8 2}$ 9105-9116.

Parekh AB \& Putney JW 2005 Store-operated calcium channels. Physiological Reviews 85 757-810.

Pedersen SF, Owsianik G \& Nilius B 2005 TRP channels: an overview. Cell Calcium 38 233-252.

Rey O, Young SH, Papazyan R, Shapiro MS \& Rozengurt E 2006 Requirement of the TRPC1 cation channel in the generation of transient $\mathrm{Ca}^{2+}$ oscillations by the calcium-sensing receptor. Journal of Biological Chemistry 281 38730-38737.

Riccio A, Medhurst AD, Mattei C, Kelsell RE, Calver AR, Randall AD, Benham CD \& Pangalos MN 2002 mRNA distribution analysis of human TRPC family in CNS and peripheral tissues. Journal of Biological Chemistry 277 12302-12309. 
Ridefelt P, Hellman P, Ljunggren O, Ljunghall S, Akerström G, Rastad J \& Gylfe E $1992 \mathrm{Ga}^{3+}$ inhibits parathyroid hormone release without interacting with the $\mathrm{Ca}^{2+}$ receptor of the parathyroid cell. Biochemical and Biophysical Research Communications $186556-561$.

Sherwood LM, Herrman I \& Bassett CA 1970 Parathyroid hormone secretion in vitro: regulation by calcium and magnesium ions. Nature 225 1056-1058.

Shoback DM \& Brown EM 1984 PTH release stimulated by high extracellular potassium is associated with a decrease in cytosolic calcium in bovine parathyroid cells. Biochemical and Biophysical Research Communications 123 684-690.

Shoback DM, Thatcher J, Leombruno R \& Brown EM 1984 Relationship between parathyroid hormone secretion and cytosolic calcium concentration in dispersed bovine parathyroid cells. PNAS 81 3113-3117.
Välimäki S, Hoog A, Larsson C, Farnebo LO \& Bränström R 2003 High extracellular $\mathrm{Ca}^{2+}$ hyperpolarizes human parathyroid cells via $\mathrm{Ca}(2+)$-activated $\mathrm{K}^{+}$channels. Journal of Biological Chemistry 278 49685-49690.

Wallace J, Pintado E \& Scarpa A 1983 Parathyroid hormone secretion in the absence of extracellular free $\mathrm{Ca}^{2+}$ and transmembrane $\mathrm{Ca}^{2+}$ influx. FEBS Letters 151 83-88.

Yokoyama K, Matsuba D, Adachi-Akahane S, Takeyama H, Tabei I, Suzuki A, Shibasaki T, Iida R, Ohkido I, Hosoya T et al. 2009 Dihydropyridine- and voltage-sensitive $\mathrm{Ca}^{2+}$ entry in human parathyroid cells. Experimental Physiology 94 847-855.

Received in final form 11 February 2010

Accepted 26 February 2010

Made available online as an Accepted Preprint 1 March 2010 